\title{
Analysis of Guided Imagery and Music Therapy on Changes in the Intensity of Dysmenorrhea Pain in SMK Visi Global Banyuwangi
}

\section{Kresna Bagus Sugiarto}

Magister of Public Health Program of Stikes Surya Mitra Husada Kediri

Email:

garisbanyuwangi@gmail.com
Received: March 12, 2019

Accepted : April 13, 2019

Published : May 10, 2019

\section{ABSTRACT}

Menstruation or menstruation is periodic vaginal bleeding due to the release of the uterine endometrium layer . Most women who experience dysmenorrhea overcome by taking painkillers on the market. There are several ways to reduce the pain when someone is experiencing dysmenorrhea is by engineering the pharmacological (drugs) and the technique of non-pharmacological (no drugs) such as distraction (music therapy) that can stimulate an increase in $\beta$-endorphin supplied by the body and guided imagery (guided imagery) which serves as a diversion from a painful stimulus thereby reducing the pain response. The research objective was to determine the effect of giving an guided imagery and music therapy on pain intensity changes dysmenorrhea. The research design used was True experimental . The study population was all students who had dysmenorrhea and large sample of 27 female students by using simple random sampling . Data collection using observation sheet then analyzed using Friedman test. The results showed that the significant probability value of $0.002<0.05$ means there is a significant difference between guided imagery, music therapy and control group on dysmenorrhea pain and there is a difference between before and after guided imagery on dysmenorrhea pain (p: $0,014<0.05$ ). There is a difference between before and after music therapy against dysmenorrhea pain ( $\mathrm{p}$ : $0.004<0.05)$. There is no difference between before and after the control group to the dysmenorrhea pain (p: 0.317> 0.05.) Among the three treatment groups most significantly affected the dysmenorrhea pain is music therapy because of its smallest significance value from the others.Based on the study, it was used as an alternative treatment in accordance with the condition of female students.

Keywords: Guided imagery, music therapy, dysmenorrhea pain

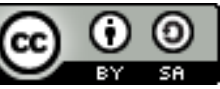

This is an open-acces article distributed under the terms of the Creative Commons Attribution-ShareAlike 4.0 International License.

\section{INTRODUCTION}

Menstruation or menstruation is periodic vaginal bleeding due to the release of the uterine endometrium layer (Janiwarty and Pieter, 2013). In general, women feel complaints of pain or abdominal cramps before menstruation that can last up to 2-3 days, starting the day before the start of menstruation. Abdominal pain during menstruation (dysmenorrhoea) perceived every woman is different, some are slightly disturbed but some are very disturbed to not be able to run daily activities 
and make it have to rest even forced to absent from school. Dysmenorrhea is defined as cyclic uterine pain that occurs before or during menstruation (Andriyani, 2013). Most women who experience dysmenorrhea overcome by taking painkillers on the market (Hesti, 2017). During the preliminary study of SMK Visi Global Banyuwangi in experiencing dysmenorrhea still use pain medication.

In the United States, menstrual pain is reported as a major cause of repeated absenteeism among female students at school. Epidemiological studies in adolescent (12-17 years old) population in the United States, Klein and Litt reported dysmenorrhea prevalence of $59.7 \%$. Of those who complained of pain, $12 \%$ weight, $37 \%$ moderate, and $49 \%$ lighter. The study also reported that dysmenorrhea causes $14 \%$ of teens often do not attend school. The study also showed that there was no significant difference in prevalence among different populations. The peak of primary dysmenorrheal incidence occurred in late adolescence and in the early 20s, dysmenorrheal incidence in adolescents was reported to be about $92 \%$. This incidence decreased with age and increased births. While in Indonesia the incidence of dysmenorrhea of $64.25 \%$ consisting of $54.89 \%$ primary dysmenorrhea and $9.36 \%$ secondary dysmenorrhea. In Surabaya, get $1.07 \%-1.31 \%$ from the number of dysmenorrhea patients come to gynecology (Ernawati, 2010).

Based on preliminary study on all female students in SMK Visi Global Banyuwangi by using pre-research interviews on 13 students who have dysmenorrhea, two girls said menstrual pain experienced did not disturb the activity, 8 female students said that menstrual pain experienced disrupt their daily activities, and 3 female students said the menstrual pain is very disturbing so can not activity.

Pain during menstruation or menstruation often complained of a woman as an un-comfortable sensation, even as the onset of the pain can interfere with the activity and force the patient to leave and routine activities for several hours or several days such as attending classes at school. The characteristic of this pain is very distinctive because it appears regularly and periodically accompanies menstruation ie discomfort in the lower abdomen before and during menstruation accompanied by nausea due to increased uterine contractions (Ernawati, 2010). Symptoms of menstrual pain include irregular, sharp pain and lower abdominal cramps that usually spread to the back, to the legs, groin and vulva (outside of the female genitals), because menstrual pain or dysmenorrhea imbalance of the hormone progesterone in the blood resulting in pain (Bavil et al, 2016). Discomfort if not addressed will affect the mental and physical function of the individual so urgent to take immediate pharmacological or non-pharmacological action / therapy. Therefore, the source of information, level of knowledge, and attitude greatly influence how the behavior of women in dealing with the happening of dysmenorrhea experienced (Ernawati, 2010).

Guided imagery is a technique that utilizes stories or narrations to influence the mind, often combined with background music. Guided imagery can serve as a diversion of painful stimuli thereby reducing the pain response (Maryam, 2012). It aims to create a state of psychological and physiological relaxation to promote good change for the body and serves as a diversion from painful stimuli thereby reducing pain. So also with music therapy. Music is one of the music that has the rhythm and the tone regularly and has a dynamic nature. Jazz music can give a flow effect to the listener. This flow effect can make the listener feel calm. Flow is a state free of emotional disturbance, so that the individual can focus on his work. Flow also raises motivation, so that adolescents who experience flow effects during dysmenorrhea can follow the learning activities well (Yulissusanti, 2013). Based on the above description, the researchers are interested to examine "Analysis of guided imagery and music therapy to change the intensity of dysmenorrhea pain in SMK Visi Global Banyuwangi"

\section{MATERIALS AND METHODS}

The design used in this research is True experimental. The population is school girls who have dysmenorrhea at SMK Visi Global Banyuwangi, 2018 , number 132 students. The sample size is 27 respondents using simple random sampling technique. Independent research variables were guided imagery, music therapy and control groups. The dependent variable is dysmenorrheal pain. Data were collected using observation, then the data were analyzed using Friedman test with significance level $\alpha$ $\leq 0.05$. 


\section{RESULTS}

Table 1. Frequency Distribution on Guided Imaging with Pain Intensity

\begin{tabular}{lcccc}
\hline \multirow{2}{*}{ Guided Imagery } & \multicolumn{2}{c}{ Before } & \multicolumn{2}{c}{ After } \\
\cline { 2 - 5 } & $\mathrm{N}$ & $\mathrm{f}(\%)$ & $\mathrm{n}$ & $\mathrm{f}(\%)$ \\
\hline No pain & - & - & - & - \\
\hline Mild pain & - & - & 4 & 44,4 \\
\hline Moderate pain & 7 & 77,8 & 5 & 55,6 \\
\hline Severe pain & 2 & 22,2 & - & - \\
\hline Pain is very severe & - & - & - & - \\
\hline Total & 9 & 100 & 9 & 100 \\
\hline
\end{tabular}

Source: Primary data of research in 2018

Based on table 1 shows that from 9 respondents before giving guided imagery mostly experienced moderate dysmenorrhoeal pain that is as much as 7 respondents $(77,8 \%)$, and after giving guided imagery mostly experience moderate dysmenorrhoeal pain that is 5 respondents $(55,6 \% \%)$.

Table 2. Frequency Distribution of Music Therapy with Pain Intensity

\begin{tabular}{lcc|cc}
\hline \multirow{2}{*}{ Music Therapy } & \multicolumn{2}{c|}{ Before } & \multicolumn{3}{c}{ After } \\
\cline { 2 - 5 } & $\mathrm{n}$ & $\mathrm{f}(\%)$ & $\mathrm{n}$ & $\mathrm{f}(\%)$ \\
\hline No pain & - & - & - & - \\
Mild pain & - & - & 7 & 77,8 \\
Moderate pain & 6 & 66,7 & 2 & 22,2 \\
Severe pain & 3 & 33,3 & - & - \\
Pain is very severe & - & - & - & - \\
\hline Total & 9 & 100 & 9 & 100 \\
\hline
\end{tabular}

Source: Primary data of research in 2018

Based on table 2 shows that from 9 respondents before giving music therapy mostly experienced moderate dysmenorrhoeal pain that is as much as 6 respondents $(66,7 \%)$, and after giving music therapy mostly experience of light dysmenorrhea pain as much as 7 respondents $(77,8 \%)$.

Table 3. Frequency Distribution in Control Group with Pain Intensity

\begin{tabular}{lcccc}
\hline \multirow{2}{*}{ Control Group } & \multicolumn{2}{c}{ Before } & \multicolumn{2}{c}{ After } \\
\cline { 2 - 5 } & $\mathrm{n}$ & $\mathrm{f}(\%)$ & $\mathrm{n}$ & $\mathrm{f}(\%)$ \\
\hline No pain & - & - & - & - \\
\hline Mild pain & - & - & 9 & - \\
\hline Moderate pain & 8 & 88,9 & - & 100 \\
\hline Severe pain & 1 & 11,1 & - & - \\
\hline Pain is very severe & - & - & 9 & 100 \\
\hline Total & 9 & 100 & & \\
\hline
\end{tabular}

Source: Primary data of research in 2018 
Based on Table 4:12 shows that from 9 respondents before giving music therapy mostly experienced moderate dysmenorrhoeal pain that is as much as 8 respondents $(88,9 \%)$, and after giving music therapy mostly experience moderate dysmenorrhoeal pain as much as 9 respondents $(100 \%)$.

Tabel 4 Uji Friedman

\section{Ranks}

\begin{tabular}{lrr}
\hline & Mean Rank & \\
\hline Guided.Imagery & 1,83 \\
\hline Music Therapy & 1,33 \\
\hline Kontrol & 2,83 \\
\hline
\end{tabular}

Test Statistics ${ }^{\mathrm{a}}$

$\mathrm{N}$

Chi-Square

Asymp. Sig.

a. Friedman Test

Based on the result / output above, obtained significant value of probalilitas equal to 0,002 . Because of the significant probability value $0.002<0.05$ then the Ho hypothesis is rejected and $\mathrm{Ha}$ accepted, meaning there is a significant difference between the provision of guided imagery, music therapy and the control group of dysmenorrhea pain.

To know the different group of meaningful on Friedman test, can be done by doing Wilcoxon signed rank test test.

\section{Test Statistics ${ }^{\mathrm{a}}$}

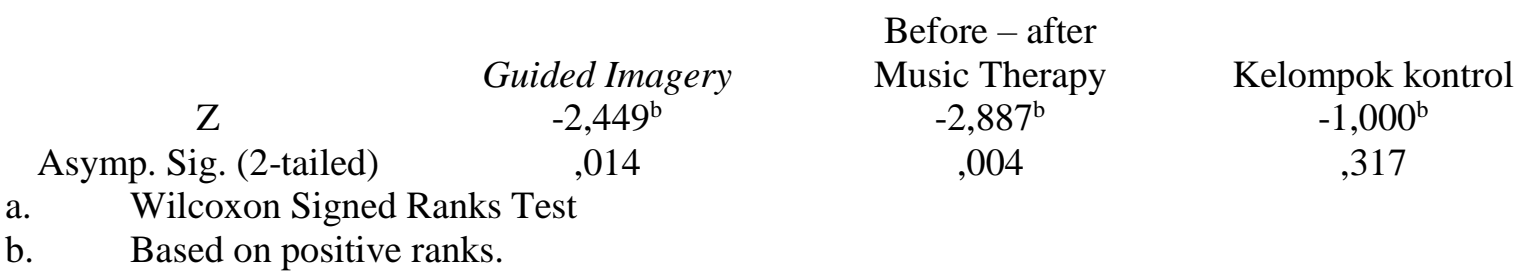

In non-paramteric tests with Wilcoxon signed rank test there is a difference between before and after giving guided imagery to dysmenorrhea pain with Asymp value . Sig. (2-tailed) $0.014<0.05$. There is a difference between before and after music therapy against dysmenorrheal pain with Asymp values. Sig. (2-tailed) $0.004<0.05$.

There is no difference between before and after the control group against dysmenorrheal pain with Asymp values . Sig. (2-tailed) 0.317>0.05.

Thus it can be concluded that among the three treatment groups the greatest effect on dysmenorrheal pain in SMK Visi Global student of Banyuwangi Regency is music therapy with Asymp value . Sig. (2-tailed) $0.004<0.005$. 


\section{DISCUSSION}

\section{A. Intensity of dysmenorrhea pain before and after guided imagery}

Based on the results of this study showed that from 9 respondents before the guided imagery mostly experienced moderate dysmenorrhoeal pain that is as much as 7 respondents $(77.8 \%)$, and after guided imagery mostly experienced moderate dysmenorrhoea pain 5 respondents $(55,6 \%)$.

The results of this study are similar to the results of previous research conducted by Vena \& Alvi (2016) who examine Guided imagery interventions to reduce anxiety. The results showed that there was influence of guided imagery intervention to decrease anxiety.

Pain during menstruation or menstruation often complained of a woman as an uncomfortable sensation, even as the onset of the pain can interfere with the activity and force the patient to leave and routine activities for several hours or several days such as attending classes at school. The characteristic of this pain is very distinctive because it appears regularly and periodically accompanies menstruation ie discomfort in the lower abdomen before and during menstruation accompanied by nausea due to increased uterine contractions (Ernawati, 2010).

Guided imagery is a technique that utilizes stories or narrations to influence the mind, often combined with background music. Guided imagery can serve as a diversion of painful stimuli thereby reducing the pain response (Maryam, 2012).

The results showed that prior to guided imagery all respondents experienced moderate to severe pain. This pain is due to increased production of prostaglandins and its release (especially PGF $2 \alpha$ ) from the endometrium during menstruation causing uncoordinated and irregular uterine contractions. The impact felt by women when experiencing pain dysmenorrhea is difficult to walk and make women have to lie in bed. To relieve dysmenorrhea pain can be done in several ways one of them is guided imagery.

In the guided imagery treatment researchers recommends students close their eyes gently. Then the researchers asked the students to take a deep breath and slowly to cause relaxation, using all five senses researchers asked students to imagine a fun place. Furthermore, the students were asked to explain their feelings and emotional and the researchers tried to help the students to explore the respondents to the shadow. This treatment is repeated 15-20 minutes so that the minds of female students become more calm and the perceived pain can be ignored.

Intentional use of imagination to obtain relaxation and distance yourself from the sensation of pain that is felt then with the guided imagery can bring individuals to present a mental picture reinforced with a sense of fun, so by giving pause or divert the conscious mind when individuals feel pain at the time of menstruation, then the pain gradually decreases. Therefore, the function rather than guided imagery is to create mental images that stimulate physical changes in the body, improve wellbeing and self-awareness.

\section{B. Intensity of dysmenorrhea pain before and after music therapy}

Based on the result of research indicate that from 9 respondents before giving music therapy most of them suffer from moderate dysmenorrhoeal discomfort that is 6 respondents $(66,7 \%)$, and after giving music therapy mostly experience of mild dysmenorrhea pain 7 respondent $(77,8 \%)$.

The results of this study are similar to the results of previous research conducted by Myriam (2014) who examines the effect of music on human stress response. The results showed there was a musical influence on the human stress response, because the significance value $<0.05$.

The problem of dysmenorrhea is a problem that is often complained when women come to the doctor or health workers associated with menstruation. This condition will get worse if accompanied by unstable psychic condition. Moreover among the women who work and must remain to work in a condition of pain (Anurogo \& Wulandari, 2011).

Dysmenorrhea results from high prostaglandin-containing endometrium, due to the influence of progesterone during the luteal phase of the menstrual cycle, prostaglandin reaches its maximum level at the start of menstruation, leading to strong myometrial contractions that can constrict blood vessels, causing ischemia, endometrial disintegration, bleeding and pain (Morgan \& Hamilton 2009). 
Before treating music therapy started, researchers looking for a quiet and comfortable place for the implementation of the treatment of music therapy can run in accordance with expectations. Then the girls were asked to have a song that corresponded with keingginannya. The treatment of this music therapy takes 15-20 minutes. The next step when the music begins to play, researchers ask students to close their eyes and take a deep breath and issued softly. Students are also asked to enjoy the music played to make the students' minds become calmer and the pain of dysmenorrhea pain can be ignored. Listening to music can make our hearts and feelings more relaxed. When a woman suffers from this dysmenorrheal pain it is necessary to distract the pain she experiences. This feeling of comfort and calm is characteristic of the condition of a person in an alpha state. At this time the brain produces the hormone serotonin and endorphins that create a feeling of comfort, calm and happy, so the intensity of pain can be reduced.

\section{Intensity of dysmenorrhea pain before and after the control group}

Based on the results of the study showed that from 9 respondents before giving music therapy, most of them suffer from moderate dysmenorrhoeal discomfort that is 8 respondents $(88,9 \%)$, and after giving music therapy, most of them suffer from moderate dysmenorrheal pain as much as 9 respondents $(100 \%)$.

The results of this study are similar to the results of previous research conducted by Novarenta (2014) who examines guided imagery to reduce pain during menstruation. The results of measurements using the numerical pain distress scale showed a decrease in the intensity of menstrual pain. This research can be a knowledge for the community that guided imagery is one alternative intervention in reducing menstrual pain.

Dysmenorrhea or menstrual pain usually occurs in the lower abdominal area, waist, and even back (Judha, Sudarti, \& Fauziah, 2012). The causes of dysmenorrhea vary, either due to disease (pelvic inflammation), endometriosis, tumors or uterine abnormalities, excessive stress or anxiety, as well as hormonal imbalances and no relation to the reproductive organs. Factors that cause primary dysmenorrhea include emotionally unstable psychiatric factors that occur in adolescent girls if not get a good illumination about the menstruation process, also associated with an increase in prostaglandin hormone that can increase myometrial contraction and able to narrow the blood vessels, so that contraction of uterine muscles (Judha, Sudarti, \& Fauziah, 2012) Most women who experience dysmenorrhea overcome by taking painkillers circulating in the market (Hesti, 2017).

In the control group researchers did not give any treatment, but the dysmenorrhea pain felt by the schoolgirl was still measured as the treatment group that was when the treatment was started until the end of treatment. If the control group there is experiencing severe pain, then the researchers provide an opportunity for girls to take the drug commonly used.

In some adolescents, primary dysmenorrhea is a torture that must be experienced every month. At the time the pain is felt, if the pain is not treated or no attempt to eliminate it, then the intensity of the pain can be increased even can change the quality of life in real way so that adolescents should be able to find the right solution to overcome them. Many ways to relieve / reduce menstrual pain, both pharmacologically and non-pharmacologically. Most students to overcome the pain of dysmenorrhea use drugs.

\section{Effect of guided imagery, music therapy and control group on the intensity of dysmenorrhea pain}

Based on the results / output Friedman test obtained a significant probability value of 0.002 . Since the probability value is significant $0.002<0.05$ then the hypothesis $\mathrm{Ho}$ is rejected and $\mathrm{Ha}$ accepted, meaning there is a significant difference between guided imagery, music therapy and control group on dysmenorrhea pain.

The results of this study are similar to previous research results. Research conducted by Rejeki (2010) who examines the effect of Mozart therapy and guided imagery on the intensity of dysmenorrhea in grade VIII students MTS Negeri Babadan Baru Yogyakarta. The purpose of this research is to know the difference of Mozart and guided imagery effect on the intensity of dysmenorrhea in grade VIII students of MTS Negeri Babadan Baru Yogyakarta, where the results 
showed that there was difference of dysmenorrhea intensity in experimental group before and after given music and guided imagery after sample $t$ test -test the significance value is $0.018<0.05$.

Guided imagery is a process that uses the power of the mind by moving the body to heal itself and maintain health or relax through communication in the body involving all senses including touch, smell, sight, and hearing (Potter \& Perry, 2010).

The benefits of guided imagery include reducing stress and anxiety, reducing pain, reducing side effects, reducing high blood pressure, reducing blood sugar levels, reducing allergies and respiratory symptoms, reducing headaches, reducing hospital costs, improving wound and bone healing, and others (Rahmayanti, Yeni, N, 2010).

Music is defined as the sound and silence that is organized through time flowing (in space), some temporary conclusions and the questions that arise are music comes from sounds, sounds derived from vibrations and vibrations are the essence of everything (Amsila 2011).

People who love pop music are significantly more responsive to conscious rules, and comfortable in relationships with others. However they may also have special developmental problems associated with anxiety of self, the development of the human body, sexual relations, and their acceptance by peers. This profile may be because pop music has such themes and emotional connections, thus reflecting and validating who they are and how they feel during this stage of development (Schwartz and Fourts, 2013).

The results showed that guided imagery and music therapy proved to show the effect of reducing the intensity of dysmenorrhea pain. Guided imagery is using one's imagination in a way designed specifically to achieve certain positive effects. In guided imagery, students are guided to create a deep impression in the mind and concentrate on the impression conveyed by the researcher, so that students gradually so that the pain experienced by female students can be reduced. Similarly, music as one form of distraction, where the attention of pain transferred to the sound of music or can be called audioanalgesik (tranquilizers). Music that goes into the ears, will vibrate the eardrum and shake the fluid in the inner ear, and will reverberate the cells of the cochlear nerve to the brain. In the brain, music affects the pituitary to release endorphins. Endorphins are a natural analgesic substance that is owned by the body and works by stimulating the ventricular dienefalon area or perişeductal grisea area that delivers pain signals to the nucleus located in the middle of the brainstem. From this nucleus the path of the fibers will descend into the spinal cord and will end in the dorsal horn where the sensory nerve spot of the peripheral pain also ends. As a result of excitation in the perişeductal grisea area, it will inhibit or suppress the transmission of pain impulses through local neurons within the area, so the pain may be squeezed or tolerated.

Although both treatments are equally aimed at diverting dysmenorrhea pain but for the siwi by listening to music is acceptable especially with the type of music they like (pop type) so as to stimulate the increase of $\beta$-endorphins supplied by the body. So when peripheral pain neurons transmit signals to synapses, synapses occur between peripheral neurons and neurons leading to the brain where substance $\mathrm{P}$ will deliver impulses. At that time, $\beta$ - fin end will block the release of $\mathrm{P}$ substance from the sensory neuron so that the transmission of pain impulses in the spinal cord becomes blocked and the pain sensation decreases. Thus distraction techniques with music therapy (both music therapy and favorite music therapy) can help a person release endorphins in the body that can inhibit the transmission of pain.

\section{CONCLUSION}

In this research can be concluded as follows:

There is difference between before and after giving guided imagery to dysmenorrhea pain at student SMK Visi Global Kabupaten Banyuwangi with Asymp value. Sig. (2-tailed) $0.014<0.05$.

There is a difference between before and after music therapy against dysmenorrhea pain in SMK Visi Global student of Banyuwangi Regency with Asymp value. Sig. (2-tailed) $0.004<0.05$.

There is no difference between before and after the control group against dysmenorrhea pain in SMK Visi Global student of Banyuwangi Regency with Asymp value. Sig. (2-tailed) 0.317>0.05.

Among the three treatment groups the greatest effect on dysmenorrheal pain in SMK Visi Global student of Banyuwangi Regency is music therapy with Asymp value. Sig. (2-tailed) $0.004<0.005$. 


\section{SUGGESTION}

1. For respondents

To improve students' knowledge and understanding especially in managing pain of dysmenorrhea using non pharmacology ie guided imagery and music therapy so that the intensity of the pain can be controlled.

2. For research sites

Continue to make efforts to educate or promote health and counseling to the students about efforts to decrease the level of pain during dysmenorrhea.

3. For educational institutions

The results of this study can be used as a vehicle for health education and reference in the school library in an effort to reduce the level of dysmenorrhea pain.

\section{For Further Researchers}

Researchers can further develop this research more deeply by combining between guided imagery and music therapy in a single treatment with 15 to 20 minute intervals.

\section{REFERENCES}

Andriyani, A. (2013). Panduan Kesehatan Wanita. Surakara: As-Salam Publisher.

Anurogo, D., \& Wulandari, A. (2011). Cara Jitu Mengatasi Nyeri. Haid. Yogyakarta: Andi.

Bavil, Dina Abadi, Dolatian, Mahrokh, Mahmoodi, Zohreh, Baghban, Akbarzadeh, A. (2016). Comparison of lifestyles of young women with and without primary dysmenorrhea. Elecetronic Journal Physician. 8(3):210714. https://www.ncbi.nlm.nih.gov/pmc/ articles/PMC4844476/.

Ernawati. (2010). Terapi relaksasi terhadap nyeri dismenore pada mahasiswi Universitas muhammadiyah semarang. http:// jurnal unimus.ac.id.vol 1 no 1. Diakses tanggal 16 Januari 2018.

Janiwarty, B., \& Pieter, H. Z. (2013). Pendidikan Psikologi untuk Bidan. Suatu Teori dan Terapannya, Yogyakarta: Rapha Publishing.

Judha, dkk. (2012). Teori Pengukuran Nyeri dan Nyeri Persalinan. Yogyakarta: Nuha Medika.

Maryam, (2012). Pengaruh Guided Imagery Terhadap Tingkat Nyeri Anak Usia 7-13 Tahun Saat Dilakukan Pemasangan Infus Di RSUD http://download.portalgaruda.org/article.php?article=4472\&val=426, Diakses tanggal 16 Januari 2018.

Morgan, G., \& Hamilton, C. (2009). Obstetri \& Ginekologi. Jakarta: EGC.

Novarenta, (2014). Guided imagery untuk mengurangi rasa nyeri saat menstruasi. http://ejournal.umm.ac.id/index.php/jipt/article/download/1575/1671.

Potter, \& Perry. (2010). Fundamental keperawatan (ed.7vol.2). Jakarta: Salemba Medika.

Rejeki. (2010). Pengaruh terapi Mozart dan guided imagery terhadap intensitas dismenore pada siswi kelas VIII MTS Negeri Babadan Baru Yogyakarta. http://digilib.unisayogya.ac.id/1722/1/NASPUB.pdf.

Schwartz, Fourts, K. A., \& Gregory. (2013). Music Preference, Personality Style, and Developmental Issues of Adolescents. Journal of Youth and Adolescene. Vol. 32: 205. 
Sabaruddin, H., F. (2017). Hubungan Pengetahuan tentang Dysmenorhea dengan Perilaku Penanganan dysmenorhea di Pesantren As-Syalafiah Mlangi Yogyakarta. Program Studi Kebidanan Diploma IV Fakultas Ilmu Kesehatan Universitas Aisyiyah Yogyakarta.

Vena, \& Alvi. (2016). Intervensi guided imagery untuk menurunkan kecemasan. 